\title{
Reka Ulang Koreografi Rejang Pala, Setelah 100 Tahun Menghilang: Sebuah Rekonstruksi Imajinatif
}

\author{
Ida Ayu Wayan Arya Satyani', I Wayan Adi Gunarta ${ }^{2}$ \\ Program Studi Seni Tari, Fakultas Seni Pertunjukan, Institut Seni Indonesia Denpasar \\ 'aryasatyani@isi-dps.ac.id
}

Rekonstruksi Imajinatif merupakan proses reka ulang terhadap koreografi tari yang sudah punah, tetapi masih meninggalkan jejak masa lampau selain jejak koreografinya. Hal ini dialami oleh Rejang Pala di desa Nongan, kecamatan Rendang, kabupaten Karangasem, yang menghilang akibat gejor Bali 1917. Kisahnya terselip dalam mitos Pan Balang Tamak yang diwarisi di desa ini. Jejak lainnya berupa hiasan kepala (serobong), dan sedikit jejak arkeologis yang diyakini oleh masyarakat setempat sebagai peninggalan Pan Balang Tamak. Minimnya sumber informasi untuk merunut jejak sejarah maupun ke'asli'an koreografi rejang ini mengantarkan peristiwa rekonstruksinya pada rekonstruksi imajinatif. Apa yang dimaksud dengan rekonstruksi imajinatif?, bagaimana prosesnya?, dan bagaimana hasilnya?, menjadi fokus pembahasan artikel ini. Metoda rekonstruksinya mengkombinasikan metoda sejarah dengan metoda konstruksi tari. Metoda sejarah meliputi heuristik (pengumpulan data), kritik (analisis, eksternal dan internal), interpretasi (analisis dan sintesis), dan historiografi (penyampaian hasil). Sedangkan metoda konstruksi tari menurut Jacqueline Smith, tersusun dalam lima langkah yaitu: konstruksi I bertumpu pada rangsang tari, konstruksi II pada motif dan komposisi, konstruksi III pada komposisi kelompok, konstruksi IV pada pengorganisasian bentuk tari, dan konstruksi V pada keutuhan karya. Pengetahuan metoda konstruksi tari menurut pandangan Smith, terhubung dengan imajinasi dan intuisi, pengetahuan tentang materi gerak, serta pengenalan bentuk melalui pengalaman estetis. Hasil pembahasan diperlukan sebagai refleksi terhadap apa yang telah dilakukan selama rekonstruksi imajinatif sejak 2017 hingga makebah (peluncuran) pada 9 April 2019. Butir-butir refleksi ini kemudian digunakan sebagai dasar untuk menyusun rancangan panyacah awig rejang, sebagai langkah awal penguatan ekosistem Rejang Pala.

Kata kunci : Rekonstrusksi Imajinatif, Rejang Pala, Desa Nongan, Panyacah Awig.

\section{Reconstructing the Choreography of Rejang Pala After 100 Years of Disappearence: An Imajinative Reconstruction}

Rekonstruksi Imajinatif (Imaginative Reconstruction) is a process of reconstructing an extinct dance choreography, but despite its choreographies, it still leaves some traces of the past. This happened on the Rejang Pala in Nongan village, Rendang, Karangasem, which disappeared as a result of the 1917 Gejor Bali. The story about the existence of this dance is inserted into the local village version of the Pan Balang Tamak myth. Other traces are in the form of headdresses (serobong), and a few archaeological traces believed by local people as a legacy of Pan Balang Tamak. The lack of sources to trace the history and originality of this rejang choreography led to its reconstruction to be rekonstruksi imajinatif (imaginative reconstruction). What is the meaning of rekonstruksi imajinatif? how did it work? and how did it turn out? are the focus of this article. The reconstruction method combines the historical method with the dance construction method. Historical methods include heuristics (data analysis), criticism (analysis, external and internal), interpretation (analysis and synthesis), and historiography (delivery of results). Meanwhile, the dance construction method according to Jacqueline Smith is arranged in five steps: construction I is based on dance stimulation, construction II on motives and composition, construction III on group composition, construction IV on dance form organization, and construction $\mathrm{V}$ on the integrity of the work. Knowledge of dance construction methods, according to Smith's view, is connected with knowledge and intuition, knowledge of motion material, recognition of forms through aesthetic experiences. The results of the discussion are desirable as a reflection of what has been done during the imaginative reconstruction from 2017 to the makebah (the premiere) on April 9, 2019. These reflection points are then used as a basis for drafting the panyacah awig rejang, as a first step to strengthen the Rejang Pala ecosystem.

Keywords : Imajinative Reconstruction, Rejang Pala, Nongan village, Panyacah Awig.

Proses Review : 2 - 28 Januari 2021, Dinyatakan Lolos: 16 Februari 2021 


\section{PENDAHULUAN}

Rejang Balang Tamak, demikian sebagian masyarakat desa Nongan, Rendang, Karangasem, menyebutnya di awal penelitian tahun 2017. Rejang ini diwarisi di Pura Balang Tamak, desa setempat. Tidak ada yang tahu kapan tercipta dan apa penyebab 'tidur' panjangnya. Desakan masyarakat sejak tahun 2005, untuk membangkitkan kembali tari rejang ini mengantarkan penata pada penelitian bertahap. Penelitian pendahuluan dilakukan pada tahun 2017, berjudul Kontinuitas Dan Perubahan Tari Rejang Balang Tamak, Di Desa Nongan, Kecamatan Rendang, Kabupaten Karangasem. Penelitian ini mengungkap sedikit demi sedikit keunikan Rejang Pala, di antaranya: kisah tentang hiasan kepala (serobong) penuh buah-buahan; hubungannya dengan mitos Pan Balang Tamak versi desa Nongan dan tidak ditemukan di desa lain maupun sumber tertulis; serta kaitannya dengan potensi subak. Rejang Pala merupakan bagian dari ritual Usaba Pala, yaitu perayaan sebagai ungkapan rasa syukur atas kelimpahan hasil subak abian/tegal. Hilangnya terminologi Usaba Pala; alih fungsi lahan subak abian menjadi subak carik/sawah; kurang tergarapnya potensi tegalan yang ada sekarang; serta kurang kuatnya sistem yang menjamin ketahanan Pura Balang Tamak pasca peristiwa gejor Bali 1917, menjadi alasan ter'tidur'nya rejang ini selama seratus tahun lebih. Rejang Pala sempat dibangkitkan pada tahun 1984 bersamaan dengan pamahayu (rekonstruksi dan upacara) Pura Balang Tamak. Tak lama kemudian, Rejang Pala kembali meninggalkan jejak berupa 11 hiasan kepala (serobong) menggunakan buah seadanya. Tidak adanya pamundut (penari), membuat serobong ini harus ditempatkan di dalam bodag (anyaman bambu) untuk kemudian diusung selama ritual berlangsung (Satyani \& Gunarta, 2018: 1-8). Sementara itu, anak-anak menarikan Rejang Dewa. Kondisi demikian membuat keberadaan Rejang Pala semakin pudar dan menjadi penting untuk direkonstruksi di tengah maraknya penciptaan rejang baru. Tahun 2019 desa adat bersinergi dengan desa dinas Nongan berinisiatif merealisasikan rekonstruksi wujud tarinya. Dengan demikian, rekonstruksi ini tidak lagi menjadi tanggung jawab pengempon Pura Balang Tamak semata, melainkan ditangani oleh desa. Wilayah desa adat Nongan cukup luas, menaungi 13 banjar adat. Desa kemudian bekerja sama dengan tim rekonstruksi dari Prodi Tari Fakultas Seni Pertunjukan Intsitut Seni Indonesia, terdiri atas Ida Ayu Wayan Arya Satyani, I Gusti Ngurah Sudibya, dan I Wayan Adi Gunarta. Rekonstruksi wujud tarinnya berlangsung dari bulan Januari sampai April 2019. Antusiasme warga desa yang begitu besar mempermudah proses rekonstruksi. Kesulitannya justru pada pemahaman rekonstruksi itu sendiri. Jika rekonstruksi adalah pengembalian seperti semula atau penyusunan kembali seperti sediakala, maka bagaimana rekonstruksi tari Rejang Pala dapat dilaksanakan?. Jejak geraknya tidak terdeteksi, sumber primer tidak ada, musik yang diwariskannya pun diragukan berasal dari era Rejang Pala.
Kendala ini, secara intuitif mengantarkan tim rekonstruksi pada peristiwa rekonstruksi imajinatif. Istilah rekonstruksi imajinatif diingatkan oleh Cok Sawitri (budayawan dan penulis) saat mengamati proses rekonstruksi Rejang Pala. Pandangannya disampaikan dalam tulisan bersambung di media sosial berjudul "Rejang Arya Satyani" (bag. 1 - 6), "Rejang Pala: Dharma Ing Pari" (bag 1), dan "Catatan Tentang Rejang Pala”, sejak 17 Maret 2019 hingga 9 April 2019. Apa yang dimaksud dengan rekonstruksi imajinatif?, Bagaimana proses rekonstruksi imajinatif Rejang Pala?, dan Bagaimana hasil rekonstruksi imajinatif Rejang Pala?, menjadi pokok bahasan artikel ini. Merujuk pada istilah rekonstruksi imajinatif maka metoda yang digunakan adalah metoda sejarah. Pada tahap konstruksi tarinnya, metoda ini tidak berdiri sendiri, tetapi memerlukan metoda penciptaan tari. Metoda konstruksi tari Jacquilene Smith dipilih karena menguraikan secara mendasar pencarian motivasi gerak, sebagaimana penata alami dalam proses rekonstruksi Rejang Pala. Smith juga menempatkan imajinasi dan intuisi sebagai salah satu elemen penting dalam proses komposisi tari.

Penulisan proses rekonstruksi imajinatif Rejang Pala ini ditujukan sebagai media refleksi. Potensi dan kelemahan yang ditemukan, diinventarisir sebagai bahan penyusunan rancangan panyacah awig, sebelum mencari acuan pada awig rejang di desa-desa kuna. Perancangan panyacah awig untuk penguatan ekosistem Rejang Pala menjadi fokus penelitian penata pada tahun 2020 .

\section{Tinjauan Pustaka dan Karya Seni}

Tinjauan pustaka rekonstruksi imajinatif Rejang Pala ditujukan pada upaya menemukan refrensi metoda rekonstruksi untuk tarian yang sudah punah. Hal ini, rupanya tidak mudah didapatkan. Beberapa artikel hasil penelitian terkait rekonstruksi misalnya: 1) "Kajian Rekonstruksi Tari Legong Raja Cina di Puri Taman Saba, Blahbatuh, Gianyar, Sebuah Proses Kreatif" pada jurnal Kalangwan Vol 5 No 1, oleh Ni Nyoman Kristina Susanti et al., (2019), menyebutkan rekonstruksi Tari Legong Raja Cina merupakan sebuah kreativitas baru yang menampilkan kekhasan bentuk dan penampilan serta nilai budaya yang dikandungnya. Rekonstruksi tersebut dilakukan dengan menggunakan konsep eksplorasi, improvisasi, dan forming yang ditawarkan oleh Alma M. Hawkins. Pernyataan tersebut belum menjawab pertanyaan sederhana pada benak penata sejak merencanakan rekonstruksi Rejang Pala. Apa yang membedakan penciptaan baru atau kreasi baru dengan penciptaan rekonstruksi?; 2) "Legong Tombol di Desa Banyuatis, Buleleng, Bali, Rekonstruksi dan Regenerasi" pada Jurnal Mudra Vol 3, oleh Ida Ayu Wimba Ruspawati (2016), tidak ditemukan pengantar pemahaman mengenai apa itu rekonstruksi. Pada metoda penciptaan karya, Ruspawati menyebutkan riset, yaitu: observasi, wawancara, dokumentasi foto dan video, serta studi kepustakaan. Pada sub bahasan terpisah disebutkan mengenai langkah-langkah penciptaan 
meliputi persiapan, eksplorasi, pemantapan, penggarapan, persiapan pertunjukan, dan pertunjukan untuk ujian Tugas Akhir. Pada penelitian awal Rejang Pala di tahun 2017, penata juga menggunakan metoda penelitian kualitatif seperti yang diuraikan Ruspawati, pada perjalanan rekonstruksinya penata menyadari bahwa metoda ini tidak cukup mewadahi permasalahan rekonstruksi tari, terutama untuk tari-tarian yang sudah punah; 3) Pada artikel berjudul "Rekonstruksi Tari Bedhaya Endholendhol di Keraton Kasunanan Surakarta Hadiningrat", pada jurnal Panggung, Vol. 28, oleh Kezia Putri Herawati (2018), dinyatakan rekonstruksi yang dilakukan pada tari tersebut berupaya mengembalikan seperti bentuk aslinya. Pada kasus rekonstruksi tari Bedhaya Endhol-endhol, rekonstruksi gerak dilakukan berdasarkan interpretasi Gusti Kanjeng Ratu Wandansari selaku penata rekonstruksi terhadap ingatan masa kecilnya saat melihat kakakkakaknya berlatih Tari Bedhaya Endhol-endhol. Pada kasus rekonstruksi Rejang Pala, informasi mengenai gerak tari ini terputus, lalu bagaimana upaya pengembalian bentuk aslinya?. Selanjutnya Herawati mengacu pada pandangan Widyastutiningrum bahwa rekonstruksi adalah bagian dari usaha merevitalisasi tari, dan revitalisasi adalah salah satu pengembangan tari yang dilakukan dengan beberapa kegiatan yaitu penggalian, rekonstruksi, reinterpretasi, dan reaktualisasi dengan tujuan menghidupkan kembali, melestarikan, mengaktualkan, dan membuat tari lebih berharga. Pernyataan ini mengakomodir dinamika pandangan mengenai penggunaan istilah revitalisasi dan rekonstruksi dalam dunia seni pertunjukan, mana yang lebih tepat serta apa perbedaannya. Herawati menyatakan bahwa rekonstruksi tari dilakukan terhadap tari yang telah mati, dan revitalisasi tari dilakukan pada seni tari yang sudah mengalami kemunduruan. Dibia dalam wawancara 26 Juli 2020 membedakan secara signifikan bahwa rekonstruksi dalam seni pertunjukan adalah penataan kembali kesenian yang sudah punah tetapi masih meninggalkan pijakan dasar sebagai bahan rekonstruksinya. Jika tidak, maka ia termasuk ciptaan baru yang terinspirasi dari kesenian lampau tersebut. Sedangkan revitalisasi adalah upaya penguatan kembali kesenian yang masih ada, tetapi mulai meredup. Dibia menganalogikan dengan sebuah bangunan candi, jika yang tertinggal adalah puing-puingnya atau pondasinya saja maka yang dilakukan adalah rekonstruksi, jika bangun candi itu masih ada dan yang perlu dilakukan sebatas membersihkan atau merapikan maka upaya yang dilakukan disebut revitalisasi.

Sumandiyo Hadi dalam makalahnya berjudul "Revitalisasi Seni Pertunjukan Tradisi Sebagai Salah Satu Cara Membangun Identitas Peradaban Budaya Bangsa" pada Seminar Nasional Seni Pertunjukan, Fakultas Seni Pertunjukan ISI Denpasar tahun 2018, menyatakan bahwa konsep yang lebih tepat untuk menata ulang seni-seni kuno yang semakin lama semakin punah, hilang atau rusak dimakan zaman, adalah revitalisasi. Konsep revitalisasi terhadap seni pertunjukan tradisi menurut pandangan Hadi adalah termasuk proses pelestarian, atau perlindungan dan pengembangan, serta pemeliharaan yang harus dilakukan secara sinergi sehingga dapat memberi "kehidupan baru" pada kesenian tersebut. Hal ini dapat dipahami, Hadi tidak ingin pelaku rekonstruksi terjebak pada tindakan penyusunan ulang konstruksi tarinya semata, tetapi mampu memberi kehidupan baru bagi konstruksi tarian tersebut agar tetap hidup dan menguat. Pada sesi diskusi Hadi juga menyampaikan bahwa revitalisasi itu gampang diwacanakan tetapi susah direalisasikan, menjamin ekosistem yang menjaga keberlanjutan hasil revitalisasi tersebut adalah 'mahal'.

Mencermati beberapa pandangan di atas, penata tertarik pada pemahaman Widyastutiningrum dalam Herawati bahwa sejatinya rekonstruksi adalah bagian dari revitalisasi. Rekonstruksi maupun revitalisasi seyogyanya berjalan sebagai satu kesatuan utuh untuk menjaga ketahanan daya hidup sebagaimana pandangan Hadi. Oleh karena itu, dapat disimpulkan bahwa yang dimaksud rekonstruksi adalah kegiatan reka ulang terhadap bentuk dan struktur tarian yang hampir maupun sudah punah, dengan melakukan riset pendahuluan untuk mengetahui elemen-elemen yang telah menghidupkannya di masa lampau dan memastikan ekosistem tersebut masih dapat dibangkitkan atau dapat diberi daya hidup baru di masa sekarang juga di masa yang akan datang. Dan rekonstruksi imajinatif adalah kegiatan rekonstruksi yang secara sadar melibatkan pemikiran imajinatif karena terputusnya sumber informasi, sehingga dalam pengerjaannya memerlukan metoda sejarah dan metoda konstruksi tari.

Tinjauan pustaka yang digunakan dalam menguatkan pemahaman mengenai konsep rejang di antaranya: Kaja dan Kelod Tarian Bali dalam Transisi oleh I Made Bandem dan Fredrik Eugene De Boer, terjemahan I Made Marlowe Makaradhwaja Bandem (2004). Pada buku ini disebutkan bahwa rejang adalah salah satu pertunjukan yang kuno, formal, memiliki wibawa dan elegansi, serta ciri khas yang sangat menawan. Rejang merupakan tarian prosesional yang dipertunjukkan oleh wanita anggota jemaah pura. Semuanya memakai pakaian formal tradisional Bali, dengan selendang (anteng) panjang yang diikatkan di pinggangnya, dan hiasan semi melingkar di kepala yang terdiri dari kerangka emas dan dihiasi bunga segar. Buku ini memberi inspirasi mengenai performa rejang tetapi belum memberi gambaran tentang apa substansi rejang, mengapa ada rejang?. Artikel penelitian berjudul "Estetika Tari Rejang Sakral Lanang di Desa Mayong, Seririt, Buleleng, Bali”, pada jurnal Mudra, Vol. 34, No. 3, oleh I Made Rianta et al., (2019), kemudian menyanggah pandangan bahwa rejang ditarikan hanya oleh wanita dengan diungkapnya Tari Rejang Sakral Lanang. Rejang ini ditarikan oleh laki-laki merepresentasikan perwujudan widyadara sebagai simbol purusa (maskulin). Perbedaan pandangan mengenai gender penari rejang, tidak cukup untuk menggali lebih jauh informasi mengenai apa itu 
rejang atau mengapa pura Balang Tamak memiliki rejang. Memetakan hubungan rejang dengan Pura Balang Tamak, sejauh ini penata masih merujuk pandangan Cok Sawitri pada artikel terdahulu berjudul "Rejang di Pura Balang Warisan Budaya Desa Nongan", pada jurnal Segara Widya, Vol. 6, No. 1, bahwa tradisi rejang kuna terkait dengan puja pari yaitu pemujaan Batari Nini atau Dewi Sri, dewi kesuburan, saat diistanakan di Bale Agung. Dengan demikian rejang berhubungan dengan kebudayaan agraris masyarakat Bali (Satyani \& Gunarta, 2018). Sebagai sumber referensi mengenai khasanah rejang yang tersebar di Kabupaten Karangasem, penata merujuk disertasi I Nengah Mariasa (2015) berjudul Rejang Kuningan Di Kecamatan Abang Kabupaten Karangasem Bali: Aspek Bentuk, Fungsi, dan Makna. Disertasi ini mendata sebaran rejang di delapan kecamatan Kabupaten Karangasem, dan menjadikan sepuluh rejang di kecamatan Abang sebagai objek penelitian. Dari penelitian ini penata mendapat banyak informasi mengenai koreografi rejang secara tertulis, meliputi ragam gerak dan perubahannya, musik tarinya, tata busananya, jumlah penarinya, hingga aturanaturan dalam pelaksanaan ritual rejang.

Beberapa tarian rejang yang menjadi rujukan dalam rekonstruksi imajinatif Rejang Pala antara lain: 1) Rejang Desa Pedawa, Kecamatan Banjar, Buleleng, yang beberapa kali penata lihat di media sosial. Salah satunya pada youtube yang diunggah oleh I Putu Armaya pada 24 Agustus 2014. Karakteristik gerak rejang di desa ini sangat sederhana dan lugas, jauh dari kesan artificial atau stilirisasi gerak; 2) Rejang Desa Kayu Putih, Kecamatan Bebandem, Karangasem. Rejang ini juga penata lihat beberapa kali di media sosial, salah satunya pada youtube yang diunggah oleh Raka Yasta Vinartha pada 4 Oktober 2016. Putaran selendang penari yang berjuntai-juntai menyentuh tanah, memikat perhatian penata saat pertama kali menonton. Tumpukan atau juntaian selendang tersebut dipasang pada bagian pinggang menyerupai rok; 3) Tarian para pamundut Rejang Pala yang penata saksikan langsung pada saat pelaksanaan usaba di Pura Balang Tamak. Beberapa kali pelaksanaan usaba, penata mendapati beragam reaksi pamundut serobong rejang, dari yang menari bersungguhsungguh sampai yang enggan bergerak, dari yang atas keinginan sendiri sampai yang di'paksa' untuk mundut serobong. Aneka ragam ekspresi yang muncul sangat menarik untuk dicermati, dan menginspirasi rekonstruksi ini.

\section{METODE PENCIPTAAN}

Istilah Rekonstruksi Imajinatif ditemukan pada metoda penelitian sejarah. Nina Herlina dalam Metoda Sejarah mengungkap keterbatasan manusia dalam mengisahkan kembali apa yang terjadi di masa lampau sebagaimana yang sungguh-sungguh terjadi, berdampak pada keterlibatan imajinasi pelaku rekonstruksi. Imajinasi tersebut hendaknya ditujukan untuk kepentingan re-kreasi, bukan kreasi. Jejak masa lampau tersebut kemudian diolah melalui langkah langkah metoda sejarah menghasilkan rekonstruksi imajinatif masa lampau itu sesuai dengan jejak-jejaknya (Herlina, 2014: 2-16). Oleh karena itu, metoda penciptaan Rekonstruksi Imajinatif Rejang Pala menggunakan metoda sejarah dan metoda konstruksi tari. Metoda sejarah yang digunakan mengacu pada pandangan Herlina, sementara metoda konstruksi tarinya mengacu pada pandangan Jacqueline Smith. Jenis sumber data yang diperoleh saat menelusuri jejak ke'asli' an koreografi Rejang Pala sebagaimana sebelum peritiwa gejor 1917, hanya berdasarkan sumber sekunder, yaitu sumber yang hanya mendengar peristiwa Rejang Pala dari orang lain. Saat rekonstruksi 1984, hanya terdapat satu sumber primer berusia 90-an tahun. Dari sumber tersebut hanya mewariskan informasi mengenai apa saja yang pernah berlangsung di Pura Balang Tamak, bukan jejak elemen dasar koreografi rejang. Selain sumber di atas, keberadaan Rejang Pala dapat dirunut melalui sumber lisan berupa mitos, atau kenangan kolektif masyarakat, sumber tertulis berupa prasasti yang mengungkap sejarah desa Nongan, serta sumber benda atau artefak yang diyakini sebagai jejak peninggalan tokoh mitos Pan Balang Tamak.

Adapun tahapan penciptaan Rekonstruksi Imajinatif Rejang Pala yang dilakukan adalah: 1) Heuristik, yaitu menghimpun data mengenai jejak sejarah, penyebab kepunahan, serta jejak koreografinya. Hal ini telah peneliti lakukan sejak tahun 2017; 2) Kritik, yaitu menganalisis keabsahan sumber melalui kritik eksternal yaitu meneliti otentisitas sumber, dan kritik internal yaitu meneliti kredibilitas sumber; 3) Interpretasi yaitu menafsirkan data berdasarkan analisis dan sintesis. Analisis adalah menguraikan data karena sebuah sumber mengandung beberapa kemungkinan, sedangkan sintesis berarti menyatukan kemungkinan-kemungkinan tersebut untuk menemukan fakta mengenai koreografi Rejang Pala. Pada tahapan ini diperlukan metoda konstruksi tari untuk menginterpretasi koreografinya, meliputi: a) Konstruksi I yaitu menentukan rangsang tari atau motivasi gerak, b) Konstruksi II yaitu penyusunan motif dan komposisi, c) Konstruksi III yaitu pengaturan komposisi kelompok, d) Konstruksi IV yaitu pengorganisasian bentuk tari, dan e) Konstruksi V yaitu mencermati kembali kesatuan atau keutuhan karya; 4) Historiografi yaitu penyampaian hasil rekonstruksi imajinatif berupa pementasan maupun tertulis.

\section{PROSES PERWUJUDAN}

\section{Imajinasi dan Pemikiran Imajinatif}

Imajinasi adalah daya untuk membentuk gambaran (imaji) atau konsep-konsep mental yang tidak secara langsung didapatkan dari sensasi pengindraan, tidak dapat dipersamakan dengan fantasi, khayalan, atau ilusi, dan mengandung tataran yang lebih tinggi serta kompleksitas yang lebih besar dari pada sekedar membayangkan (Tedjoworo, 2001: 21-25). Karena imajinasi adalah daya, 
maka ia berkaitan langsung dengan manusia yang memiliki daya tersebut. Imajinasi mendorong manusia untuk selalu kreatif menggunakan daya ciptanya.

Jacquline Smith dalam Komposisi Tari Sebuah Petunjuk Praktis Bagi Guru, terjemahan Ben Suharto (1985: 7681), dengan tegas menyatakan bahwa seorang penata tari tidak dapat berkarya tanpa menggunakan imajinasinya. Pengetahuan metoda penciptaan tari bukan satu-satunya penentu keberhasilan proses penciptaan tari. Terdapat empat hal yang memengaruhi kinerja seorang penata tari, yaitu: 1) Imajinasi dan intuisi, 2) Pengetahuan materi gerak, 3) Pengetahuan metoda konstruksi, dan 4) Pengenalan bentuk melalui pengalaman estetis. Imajinasi terletak pada struktur rangsang atau stimulus, ia merupakan reaksi awal seorang penata tari terhadap stimulus isi materi, kemudian secara bertahap menemani penata tari dalam fase-fase penyusunan koreografinya mulai dari menemukan motif hingga tersusun sebagai bentuk tari. Imajinasi bersumber dari pengalaman estetis. Semakin banyak pengalaman estetis yang dialami, maka semakin banyak tabungan imajinasi yang dimiliki seorang penata. Pengalaman estetis adalah pengalaman yang mampu mengusik kepekaan intuitif, kedalaman rasa, mengundang interpretasi serta keinginan untuk berkarya bagi seorang penata. Untuk merekonstruksi Rejang Pala misalnya, penata tak dapat lepas dari pengalaman menonton beragam rejang. Dari sekian banyak rejang yang penata lihat, terdapat beberapa rejang yang mengusik kesadaran estetis penata dan secara intuitif hadir pada proses kreatif penata. Selain pengalaman menonton beragam rejang, rekonstruksi imajinatif Rejang Pala juga dipengaruhi oleh pengalaman estetis selama menelusuri asal muasal rejang, yaitu: tentang subak, tentang Pura Balang Tamak, tentang sejarah desa Nongan, dan mitos Pan Balang Tamak yang berkembang di desa Nongan. Pengalaman estetis bersifat individual, demikian pula imajinasi yang ditimbulkannya. Penguraian imajinasi dalam pikiran menuju sebuah komposisi tari inilah oleh Smith disebut sebagai pemikiran imajinatif atau pemikiran orisinal. Pemikiran imajinatif memerlukan pengetahuan tentang materi gerak dan pengetahuan tentang teknik khusus konstruksi tari. Sementara itu, imajinasi dan pengetahuan tersebut patut dibarengi dengan kesadaran intuisi. Kesadaran intuisi diperoleh secara naluriah dan didisiplin oleh pengetahuan bentuk yang ditempa secara terus-menerus sehingga berada pada bawah sadar. Demikian ke empat hal di atas saling terhubung, bertautan, dan senantiasa mendesak kinerja seorang penata tari.

\section{Tahapan Rekonstruksi Imajinatif}

Elemen koreografi yang direkonstruksi, penata klasifikasikan menjadi empat elemen yaitu: kostum, jumlah penari, gerak, dan musik. Penjabaran tahapannya dilakukan dengan merunut metoda penciptaan yang digunakan yaitu metoda sejarah dan konstruksi tari. Berikut adalah proses perwujudan Rejang Pala dari tahap heuristik, kritik, hingga interpretasinya.

\section{Kostum}

Satu hal yang pasti adalah serobong Rejang Pala tersusun oleh buah-buahan. Data ini diperoleh dari sumber lisan berupa mitos Pan Balang Tamak dan kesaksian masyarakat setempat. Informasi mengenai bentuk serobong yang diperoleh beragam. Ada yang menyebut memang berbentuk persegi empat seperti gelungan Rejang Dewa, ada yang menyebut dahulu bentuknya beragam, ada yang bentuknya setengah lingkaran. Mengenai tata busana, Ida Pedanda Gde Nyoman Djelantik sempat menyebut matoros (sebutan untuk pemakaian kain dengan stagen untuk menutupi badan bagian atas). Sumber lain, menyebut berpakaian ke pura saja (kebaya, kain, dan selendang). Pada dokumentasi foto tahun 1987, tiga tahun setelah rekonstruksi, didapat data bahwa para penari mengenakan busana adat ke pura, terdapat juga penari yang mengenakan pakaian casual (atasan dan rok sebatas lutut).

Penata menyangsikan tatanan busana yang terdapat pada foto di atas adalah tatanan busana yang dikenakan saat sebelum gejor 1917. Berkain dan berkebaya bagi rejang kiranya untuk alasan praktis. Berpakaian casual ke pura bagi anak-anak di tahun 80-an adalah hal yang lumrah, sebagaimana penata pernah alami. Matoros, seperti yang disampaikan oleh Ida Pedanda Gde Nyoman Djelantik menurut pandangan penata lebih mendekati kondisi sebenarnya, merujuk pada tatanan busana rejang yang ada di desa-desa kuna di Kabupaten Karangasem. Ida Pedanda tidak dapat menyampaikan secara detail rupa dan ragam kostum yang dikenakan, setidaknya kata kunci matoros dan keberadaan rejang di beberapa desa kuna, dapat dijadikan refrensi rekonstruksinya. Mengenai bentuk serobong yang diwariskan sekarang, menyerupai Rejang Dewa, menurut hemat penulis adalah karena bentuk ini yang sedang populer dan praktis, ukurannya lebih kecil jika dibandingkan dengan serobong rejang di desa-desa pewaris tradisi rejang. Penata juga mencermati beberapa kali piodalan di pura Balang Tamak sempat menghaturkan Rejang Dewa. Sedangkan Informasi dari sumber lisan mengenai bentuk serobong ini di masa lampau beragam. Ni Putu Asti (53 tahun), pangayah yang bertugas menyiapkan upakara menyebut "ampun sekadi niki tami katami”" (terjemahan: memang seperti ini diwarisi turun-tumurun), Ida Pedanda Istri Ratna Kanya, menyebut bentuknya "magenepan" (beraneka ragam). Ida Pedanda Istri merupakan tapini (ahli upakara) di Desa Nongan, termasuk juga bertanggungjawab terhadap upakara yang dilaksanakan di Pura Balang Tamak. Hanya saja, sebagaimana sumber lainnya, Ida Pedanda Istri pun mengetahui berdasarkan cerita, tidak pernah melihat langsung. Pada foto tahun 1987, nampak dua bentuk gelungan yaitu: persegi empat dan melingkar.

Berdasarkan analisis di atas dan berkembangnya jumlah penari Rejang Pala menjadi rejang daha, rejang alit, dan rejang lingsir, maka interpretasi penata mengenai 


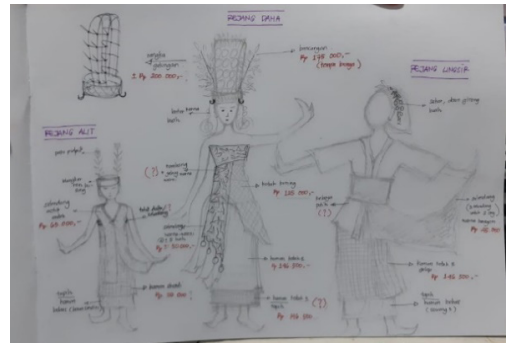

Gambar 1: desain kostum dan estimasi biaya

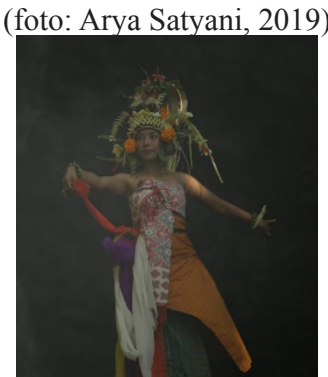

Gambar 2: dami kostum rejang daha digunakan saat shooting dokumenter (foto: tim dok., 2019)

hiasan kepala ini adalah sebagai berikut. Serobong rejang untuk rejang daha tetap mempertahankan bentuk persegi, hanya saja ukurannya dibuat lebih besar. Jika mendengar cerita-cerita krama panyungsung pura Balang Tamak, tentang aneka ragam buah yang menghias serobong, yakni: buluan (rambutan), ceroring (duku), kepundung (sejenis duku), juet (jamblang), boni (buni), bahkan jeroti (jeruk Bali) sebagai lenter atau hiasan yang menjuntai di samping telinga, penata membayangkan serobong ini memiliki kerangka yang kuat. Pemasangan jeroti, penata perkirakan dalam kondisi telah dikupas atau diiris. Penata sempat melihat dokumentasi proses pemasangan hiasan kepala rejang di Desa Tumingal yang menggunakan rangka dari rautan bambu. Pemasangannya nampak rumit karena rangka dipasang langsung pada kepala dan menggunakan rambut untuk menguatkan, atau sebaliknya rangka tersebut menguatkan penataan rambut menyerupai bentuk-bentuk (mandala) tertentu. Kerumitan tersebut tidak mungkin penata tawarkan pada pangempon Pura Balang Tamak. Untuk menyiapkan buah kelengkapan serobong saja mereka sudah 'kewalahan'. Oleh karena itu, desain rangka serobong ini dibuat menyerupai rangka gelungan, dibalut dengan ron busung (daun enau dan janur), buah, dan bunga. Hiasan kepala rejang alit (anakanak) dibuat sederhana berbentuk melingkar disebut blengker (hiasan kepala berbentuk lingkaran pada payas agung Karangasem). Bentuk lingkaran ini terekam pada foto 1987, digunakan oleh seorang penari Rejang Pala, di atasnya terdapat rangkaian bunga menyerupai bancangan seperti pada gelungan arja, gambuh, ataupun legong kraton, jumlahnya satu, dipasang di tengah. Bentuk ini mengingatkan penata pada tatanan hiasan kepala rejang di desa Pedawa, Kabupaten Buleleng, blengker tersebut terbuat dari logam (emas atau perak). Hal ini masuk akal, mengingat masyarakat Desa Nongan dahulu banyak yang mengungsi, menyebar, dan menetap di Buleleng,

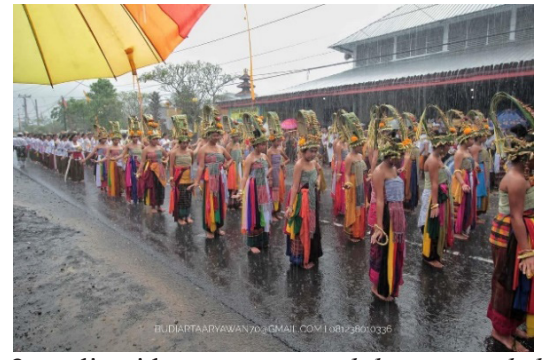

Gambar 3: realisasi kostum rejang daha saat makebah (foto: Budiarta Aryawan, 2019)

sebagian besar di daerah Banyuatis. Bendesa Adat Nongan perioda 2009 - 2015, mengisahkan setelah gejor 1917, perekonomian di desa Nongan surut, beberapa warga mengungsi ke Buleleng untuk menjadi buruh petik kopi dan cengkeh. Warga inilah yang membawa bibit cengkeh dan kopi ke Desa Nongan sehingga perkebunan di desa Nongan sempat di dominasi pohon cengkeh dan kopi (wawancara 7 Agustus 2020). Blengker rejang alit, disederhanakan agar terasa ringan di kepala anak-anak, tidak dihiasi bancangan bunga tetapi diganti dengan buah-buahan yang dipasang menurut kreativitas orang tua masing-masing. Tujuannya untuk melihat segala kemungkinan, juga untuk menjaga keragaman di tengah hobi penyeragaman yang sedang menimpa seni tari Bali kini. Pada hiasan kepala rejang lingsir ditandai dengan juntaian buah yang diselipkan pada sanggul.

Untuk tata busana, mengingat desa Nongan tidak memiliki produk sandang yang khas, penata membuat sketsa untuk didiskusikan bersama panitia rekonstruksi desa, kemudian membuat dami satu set kostum rejang daha, sekaligus untuk mengetahui estimasi biaya yang diperlukan. Keinginan tim untuk menggunakan kain bebali harus ditangguhkan karena harga kain ini cukup mahal. Pada upacara tertentu yang memerlukan kain gringsing misalnya, beberapa masyarakat meminjam ke geria (rumah pendeta). Harga rangka serobong berbahan rotan yang cukup tinggi diatasi oleh warga yang berkenan menduplikasi rangka tersebut menggunakan material bambu dengan harga yang lebih terjangkau serta lebih ringan di kepala. Pengadaan kostum hendaknya tidak menjadi beban masyarakat, oleh karena itu prajuru (perangkat) desa memutuskan beberapa material dibelikan oleh pihak desa, sisanya disiapkan oleh masing-masing warga tanpa menuntut keseragaman. Pengadaan kostum menjadi tanggung jawab sekeha teruni desa dengan pengawasan prajuru desa. Berikut adalah desain kostum Rejang Pala.

\section{Jumlah Penari}

Jumlah serobong yang diwariskan sejak rekontruksi 1984 adalah 11 buah, tidak berani kurang ataupun lebih, demikian keterangan yang diperoleh dari tukang banten (pembuat sesaji) di Pura Balang Tamak. Ida Pedanda Gde Nyoman Jelantik Dangin menyebutkan jumlah yang berbeda, pertama menyebut angka 9 dikaitkan dengan dewata nawa sanga, kemudian pada wawancara berikutnya menyebut angka 11, yang penting jumlahnya ganjil. Data pada mitos/ 
cerita Pan Balang Tamak mengenai jumlah rejang tersirat pada adegan saat raja memerintahkan seluruh warga desa untuk menghaturkan penari rejang, termasuk Pan Balang Tamak. Saat itu seluruh rejang berpakaian indah dengan bunga emas, hanya seorang yang mengenakan hiasan lusuh bergelung buah-buahan, hingga jadi bahan tertawaan warga. Rejang tersebut adalah anak Pan Balang Tamak.

Bilangan sebelas adalah pemberian Ida Pedanda Gde Djelantik Dangin ketika rekonstruksi 1984. Ida Pedanda tidak ingat apakah jumlah tersebut berdasarkan informasi Mangku Suweda atau karena hal lain, yang jelas jumlahnya harus ganjil. Pada mandala upakara, bilangan sebelas (solas) kerap ditemukan, misalnya tumpeng solas, sayut solas, pengarasan dengan 11 uang kepeng, dan sebagainya. Meski demikian, sampai saat ini makna bilangan 11 atau mengapa Rejang Pala berjumlah 11 masih menjadi misteri bagi penata. Jika merujuk pada rejang di desa-desa kuna sebagaimana diungkap oleh Mariasa pada disertasinya (2015: 185-201), masing-masing desa memiliki kebijakan dalam menentukan jumlah penari, ada yang berdasarkan jumlah kepala keluarga, tempek, dan jero desa. Umumnya mereka yang wajib kena ayahan rejang adalah yang mendapat hak ayahan karang desa. Jumlahnya beragam dari 20 sampai 30-an penari. Pada cerita Pan Balang Tamak, raja memerintahkan seluruh krama membawa rejang, hanya satu bergelung pala.

Penata mempertahankan jumlah sebelas sesuai keyakinan masyarakat panyungsung Pura Balang Tamak. Jumlah sebelas ditempatkan sebagai penari inti yang akan menari di setiap Usaba Pala di Pura Balang Tamak. Terkait pelaksanaan Usaba Desa, sebelas rejang ini mengikuti prosesi mendak Batara Dalem Kupa dan Batara Dalem Nongan di jeroan Pura Pasamuhan Agung. Untuk kebutuhan regenarasi, penata menawarkan kepada panitia rekonstruksi desa, bahwa penari Rejang Pala sebaiknya terdiri dari remaja dan anak-anak, melibatkan 13 banjar di bawah naungan Desa Adat Nongan. Keterlibatan anak-anak ini meniru tradisi rejang di desa Tenganan Pagringsingan. Desa tersebut memiliki prosesi di mana anak-anak bahkan balita dilibatkan sejak dini dalam ritual rejang. Diluar dugaan, ibu-ibu PKK menyatakan ingin terlibat sebagai penari. Awalnya Bendesa Adat Nongan menentukan sekitar 150 penari. Penata membaginya sebagai berikut: 70 rejang daha (remaja), 40 rejang alit (anak-anak), dan 40 rejang lingsir (ibu-ibu). Keinginan masyarakat membludak, jumlah penari anak-anak dan ibu-ibu terus bertambah setiap kali latihan, berbeda dengan jumlah penari daha atau remaja yang membutuhkan perjuangan tim untuk mengumpulkannya. Pada saat ngebah (peluncurannya), jumlah penari mencapai 200 lebih. Bagi penata, ini adalah hal positif yang patut disambut dalam rangka memberi daya hidup baru pada rekontruksi.

\section{Gerak}

Sumber informasi untuk menelusuri gerak rejang pada masa sebelum gejor Bali 1917 sangat sulit ditemukan. Tidak ada sumber tertulis baik itu berupa dokumen, lontar, piagam, atau awig. Sumber benda bersifat ornamental (relief), maupun fotografis (potret hingga film) juga tidak ditemukan. Sementara itu, sumber lisan hanya diperoleh dari sumber sekunder. Sejauh pengamatan penata sejak tahun 2005, gerak tari yang dilakukan pamundut serobong rejang di Pura Balang Tamak adalah sekehendak pamundut. Tidak ada unsur keteraturan, keseragaman, atau komposisi sebagaimana dapat dilihat pada rejang di desa-desa kuna yang masih lestari. Penyebabnya adalah tidak adanya pamundut rejang yang pasti, semua dilakukan secara spontan, ditunjuk ketika upacara sedang berlangsung. Ada yang mundut dengan ikhlas, ada juga yang mundut karena terpaksa. Perasaan itupun terpancar pada gerak yang dilakukannya. Pamundut yang berkenan menari saat mundut serobong, bergerak sekehendak dan setulus hati. Gerakan mengayun, melambaikan tangan sekehendak hati ini di beberapa daerah digunakan dalam prosesi mamendet, ada juga yang menyebut nglegong. Dalam bahasa Bali gerakan seperti itu bisa disebut ngalelente.

Konstruksi gerak rejang di tahun 1984 dipercayakan kepada almarhum Nini Telaga, saat itu diperkirakan berusia 60an tahun, artinya Nini Telaga lahir setelah gejor Bali 1917. Pewarisan pasca rekonstruksi yang dilakukan Nini Telaga hanya sampai pada generasi pertama. Ida Ayu Putu Darmayani (45 tahun), salah satu penari generasi pertama menyatakan menari sejak umur 7 tahun hingga tamat Sekolah Menengah Pertama. "Setelah Nini Telaga semakin tua, generasi pertama rejang rata-rata sudah remaja dan berhenti menari, pamundut (penari) rejang mulai sulit didapat". Sejak saat itulah serobong ini dipundut oleh siapa saja yang mau, jika tak ada pamundut maka ditempatkan di dalam bodag (keranjang bambu), di arak dalam prosesi upacara sebagai tanda bahwa prosesi rejang telah dilangsungkan. Berdasarkan penuturan Ida Ayu Putu Darmayani, gerakan yang diajarkan oleh Nini Telaga sifatnya spontan, langsung diturunkan pada saat upacara berlangsung. "Di sana langsung, disuruh gini aja tangannya" ungkap Ida Ayu Putu Darmayani sambil memperagakan beberapa gerakan, seperti ngelung (mengayun ke belakang), ngembat (salah satu lengan direntangkan ke kanan atau ke kiri), ngileg (menggerakkan kepala ke kanan dan ke kiri, sumber gerak berasal dari leher), dan nyeledet (menggerakkan bola mata ke kanan ataupun ke kiri). "Isinin nyeledet kapah-kapah" (terjemahan: diisi nyeledet sekali waktu), demikian jawab informan ketika ditanyai kembali mengenai adanya gerak seledet dalam rejang ini. 


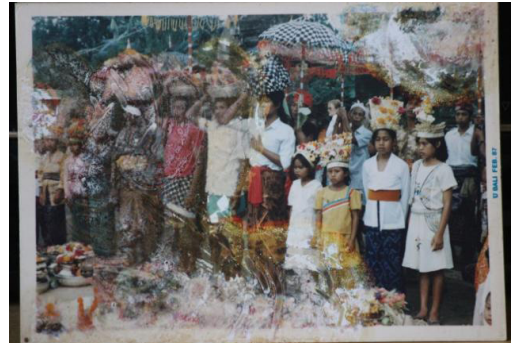

Gambar 4: Rejang Pala pada prosesi Usaba Pala Februari 1987 (foto: dokumentasi Geria Alang Ajeng Nongan)

Apa yang diperagakan oleh Ida Ayu Putu Darmayani, penata amati serupa dengan gerakan Rejang Dewa, yang lahir sekitar tahun 70-an. Informasi tentang adanya seledet (gerakan mata), juga tak lazim ditemui pada rejang di desa-desa kuna. Sementara itu sumber-sumber lisan lain dari mereka yang masih berkenan menarikan serobong rejang pada pelaksanaan usaba menyebutkan "Nak kentenkenten manten, tityang nenten midep" (terjemahan: hanya begitu saja, saya tidak bisa) sambil menggerakkan tangan melambai ke samping, kemudian merujuk "Nini Telaga wau uning" (terjemahan: Nini Telaga baru tahu). Cok Sawitri menyebut pada kisaran abad $10 \mathrm{M}-12 \mathrm{M}$ adalah masa tumbuhnya tradisi rejang, kemudian abad $15 \mathrm{M}$ hadir pendet atau papendetan. Di era milenial ini, lahir beragam rejang dengan fungsi yang berbeda dari fungsi awalnya (ritual puja pari, pemujaan terhadap Btari Nini yang bermuara pada budaya agraris). Selain kelahiran rejang 'baru' yang masih difungsikan sebagai sarana upacara, rejang pun menemui era kreasi diperuntukkan sebagai seni pertunjukan (tontonan). Hal ini tak lepas dari perubahan kultur masyarakat pendukungnya. Perubahan karakter gerak rejang akibat pengaruh palegongan juga ditemukan Mariasa pada rejang kuningan di desa Tista dan Kesimpar (Mariasa, 2015:170). Dengan alasan ini, penulis memilih untuk menggunakan rejang di beberapa desa kuna secara acak sebagai sumber imaji gerak.

Proses menginterpretasi gerak Rejang Pala, penata uraikan dengan metoda konstruksi tari Smith. Pada metoda kontruksi I, disebutkan 5 macam rangsang tari atau sesuatu yang memotivasi terciptanya gerak. Rangsang tari ini terdiri dari rangsang dengar (gerak termotivasi oleh segala sesuatu yang didengar, misalnya oleh musik), rangsang visual (gerak termotivasi oleh gambar, patung, objek, pola, wujud, dsbnya), rangsang kinestetik (gerak termotivasi oleh gerak itu sendiri), rangsang peraba (gerak termotivasi oleh respons kinestetik terhadap segala sesuatu yang dirasa oleh indra peraba), dan rangsang gagasan (gerak termotivasi oleh intensi pikiran untuk menyampaikan gagasan) (Suharto, 1985: 20-23). Apa yang memotivasi lahirnya gerak pada rekonstruksi Rejang Pala? Awalnya adalah imaji tentang serobong penuh buah-buahan. Besar dan beratnya serobong dalam imaji penata akan membuat posisi kepala sedikit menengadah, dagu mengarah ke bahu kanan atau bahu kiri, untuk menjaga proporsi tubuh yang agak rebah ke belakang tetap seimbang dan estetis.



Gambar 5: Ida Ayu Putu Darmayani (45 th), penari generasi pertama rekonstruksi 1984 (foto: Arya Satyani, 2017)

Rangsang visual tidak saja datang dari bentuk serobong, rasa takjub penata saat menyaksikan dokumentasi rejang desa Pedawa Buleleng mengusik daya imaji penata. Geraknya lugas, satu pola gerakan pada rejang ini seolah sedang memamerkan keindahan hiasan kepala yang dimilikinya, berbeda dengan rejang desa Bebandem atau rejang Kuningan desa Abang yang rata-rata posisi kepalanya tegak, fokus pada menarikan selendang. Gerak dari rangsang visual ini kemudian berlanjut pada rangsang kinestetik, di mana gerak mengalir menimbulkan gerak berikutnya. Tangan kanan diletakkan seolah menahan beban berat gelungan (posisi tangan seputar belakang bawah telinga). Dari posisi tersebut bergerak seakan mengusap daerah telinga yang dihiasi prekapat/antinganting buah, diistilahkan sebagai ngarna (berangkat dari kata karna artinya telinga). Gerak tangan kemudian mengalir ke depan dada mengikuti juntaian buah, berakhir di bagian pinggul kanan dengan posisi tangan telungkup. Pada beberapa artefak, menurut keyakinan purba, entah itu relief candi, arca, maupun tari-tarian, dada dan pinggul seringkali digunakan sebagai simbol kesuburan. Dari pinggul, gerakan berlanjut mengalun memutar pinggul setengah lingkaran dipandu oleh tangan kanan menggapai atau membentang sejauh mungkin, tetapi level tangan dijaga tetap setara pinggul. Kemudian jeda, berdiri, kaki kiri melangkah ke depan, kepala menoleh ke arah tangan kiri yang merentang ke arah kiri sejajar bahu, menjentikkan jemari. Gerakan ini diambil dari salah satu gerak yang terdapat pada gambuh style Padang Aji. Setelah fase jeda ini, kaki diayun ke depan (matayungan), kedua tangan menjuntai ke bawah, telapak menghadap ke belakang menghempas ke belakang, kemudian mengayun ke arah dada dengan posisi telapak tangan ke arah dada, kemudian gerakan beralih ke pinggul, motivasi geraknya adalah menggerakkan tumpukan selendang (oncer) yang berada di seputar pinggul. Penata mengimajikan oncer itu adalah seikat padi, jika digerakkan memutar ke kanan dan ke kiri menimbulkan efek terbang pada ujung-ujungnya. Gerak ini terinspirasi dari rejang desa Kayu Putih, Bebandem saat mereka memutar pinggul ke bawah dan berdampak pada kibasan selendang yang dipasang seperti rok melingkar dari pinggang, berjuntai-juntai, menyentuh tanah. Dalam hal ini gerak muncul dari rangsang visual dan rangsang peraba, kemudian menghasilkan rangsang kinestetis, mengalir melahirkan gerak-gerak berikutnya. Gerak memutar oncer, diakhiri ngotes (menghempas) selendang 

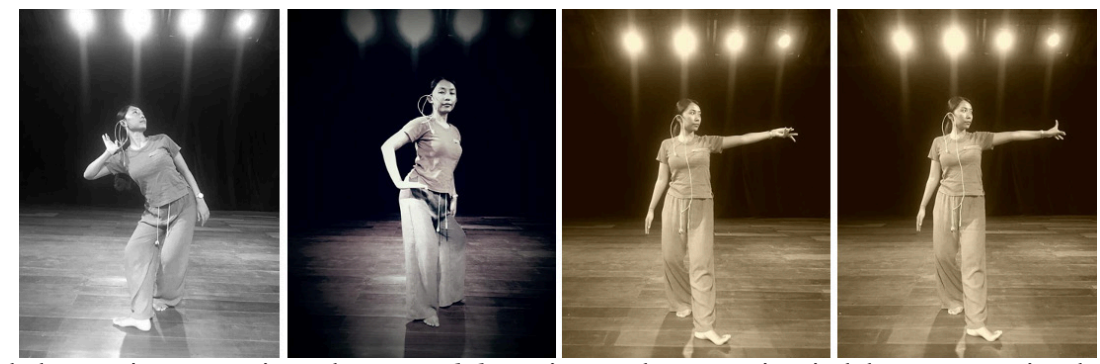

Gambar 6 : beberapa interpretasi gerak rejang daha Rejang Pala, termotivasi oleh rangsang visual dan kinestetik

(foto: Arya Satyani, 2019)

oleh tangan kiri. Selanjutnya kaki kanan diletakkan di depan, gesture badan empak (rebah) seperti dahan pohon yang patah atau padi terhempas angin, sementara kaki ngingsak meniru gerak kaki ketika bertemu gulma atau hama di tanah, dilakukan kanan dan kiri. Menyelesaikan rangkaian gerakan ini tangan kanan ngotes selendang ke belakang, kepala sekedar menoleh ke belakang kemudian mentang lurus ke kanan sejajar bahu, jari dijentikkan dari ujung kelingking. Proses menemukan teba gerak tersebut penata lakukan bersama seorang penari sebagai medium eksplorasi. Kemudian penata tuangkan kepada salah seorang pemudi desa Nongan, agar diteruskan kepada rekan-rekannya, sebelum tim rekonstruksi hadir ke desa untuk latihan bersama. Sepotong demi sepotong teba gerak yang diperoleh, penata unggah di media sosial dengan harapan mendapat tanggapan. Terdapat satu gerak di mana tangan seolah menyentuh tanah dengan posisi sebelah lutut hampir menyentuh tanah. Gerak ini dikritisi oleh Cok Sawitri, bahwa dalam tradisi rejang, tidak ada penari sampai 'bersimpuh'. Penata introspeksi diri, mengingat kembali 'aturan' rejang, rupanya penata salah menafsirkan arti kata makepu pada Rejang Ilut, desa Jasri, Karangasem. Gerak di atas segera penata ganti dengan gerak lain, tersusun sebagaimana uraian pada paragraf di atas. Konstruksi gerak rejang alit berangkat dari gagasan tentang gerak yang sederhana, mengandung keriangan, dan dapat diikuti oleh anak-anak bahkan balita sekalipun tanpa perlu latihan. Gerak tersebut di antaranya, bermain selendang, berlari, dan beberapa gerak meniru rejang daha. Pada rejang lingsir, rangsang kinestetik mendominasi proses penciptaan geraknya. Properti bokor kecil berisi sesaji dan selendang juga memotivasi timbulnya gerak, di samping rangsang gagasan mengenai simbol-simbol yang ingin disampaikan misalnya ngayab atau menghaturkan sesaji. Sebagai tarian ritual, konstruksi tarian ini sangatlah sederhana, tidak melalui proses improvisasi yang intens atau rumit untuk mengembangkan variasi motif gerak. Dilihat dari motif-motif gerak yang dihasilkan, dapat disampaikan bahwa rejang termasuk dalam tipe tari murni yang secara ekslusif hanya memandang gerak itu sendiri, dengan mode penyajian pada rentang mime hingga simbolis yaitu dari peniruan hingga penggambaran simbol secara orisinal.

Metoda konstruksi II Smith adalah mengenai bagaimana penyusunan motif gerak ke dalam komposisi. Pada uraian di atas dapat dilihat satu frase gerak Rejang Pala terdiri atas tujuh motif gerak, ditambah dengan motif ke delapan adalah pernyataan ulang dari motif ke tiga yang dilakukan dengan sisi tubuh yang lain. Satu frase gerak ini kemudian diulang kembali sama persis dengan sisi tubuh lainnya. Smith menguraikan 7 cara pengulangan sebagai elemen konstruksi. Pengulangan yang paling sederhana disebut pernyataan ulang yaitu penuangan kembali secara persis, yang dapat dilakukan dengan sisi lain tubuh penari (Suharto, 1985: 40). Pernyataan ulang pada Rejang Pala dilakukan sebaliknya atau nungkalik ini bertujuan agar genap satu putaran penuh disebut ngewindu.

Pada Metode Konstruksi III, Smith menguraikan tentang konstruksi motif menuju komposisi kelompok, menyangkut aspek ruang dan waktu. Kelompok hendaknya dipandang sebagai elemen ekspresif dengan mempertimbangkan jumlah, penempatan ruang, dan wujud kelompok. Sebagai tarian ritual, rejang tidak dibentuk berdasar pertimbangan ekspresif sebagaimana seni pertunjukan apalagi tontonan. Dalam hal penentuan jumlah penari misalnya, di desa kuna ditentukan oleh jero desa (warga desa pokok yang mendapat hak ayahan desa/ tanah desa). Pada rekonstruksi Rejang Pala jumlah kelompok masih berdasarkan antusias warga. Apsek ruang yang ditemukan hampir pada setiap rejang di Bali yaitu majajar (berbaris) dan mider atau makideh (pola melingkar, ujung belakang bertemu ujung depan disebut nemu gelang) dalam pola-pola simetris. Aspek ruang Rejang Pala sangat sederhana hanya dengan membagi ruang pentas menjadi 3 bagian untuk masingmasing kelompok, anak-anak di hulu, di tengah adalah barisan rejang daha, dan di hilir adalah rejang lingsir, masing masing ditata berbaris berbanjar (simetris). Pada Rejang Pala prosesi mider dilakukan mengitari pura Balang Tamak atau Pura Desa pada mandala utama yang disebut jeroan, dan dilakukan hanya oleh rejang daha. Secara garis besar, konstruksi aspek waktu Rejang Pala pada masingmasing kelompok adalah rampak simultan, yaitu setiap penari dalam penari melakukan gerak yang sama pada waktu yang sama. Jika dilihat konstruksi antara kelompok satu dengan yang lain, akan nampak kontras secara simultan, karena masing-masing kelompok membawakan koreografi berbeda sesuai karakteristiknya. Pada tahap ini, latihan sektoral bagi masing-masing kelompok sangat diperlukan, untuk memastikan penguasaan materi secara kelompok. 


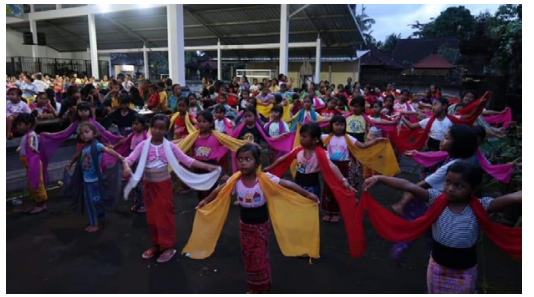

Gambar 7: tahapan konstruksi motif menuju komposisi kelompok rejang alit (foto: Arya Satyani, 2019)

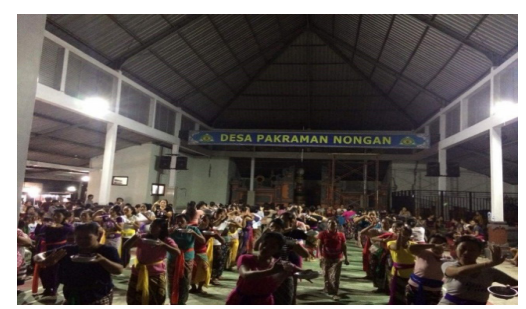

Gambar 8: tahapan konstruksi motif menuju komposisi kelompok rejang lingsir (foto: Adi Gunarta, 2019)

Pada metoda konstruksi IV, Smith berbicara tentang pengorganisasian bentuk (waktu dan tenaga dalam hubungannya dengan setiap gerak). Pada fase ini, bagaimana dinamika dan struktur tarian ini dibentuk menjadi fokus penataan. Pada tradisi rejang di desa kuna struktur tariannya terkait dengan struktur ritual, ada masanya mereka berbaris saja lalu ritual rejang usai, atau mengitari upakara yang sedang dihaturkan oleh pemangku seperti di desa Bebandem disebut prosesi mamanda, atau di desa kuna yang masih memiliki Bale Agung, rejang memiliki prosesi mengitari Bale Agung. Alunan gending rejang kuna sangat meditatif. Generasi yang lahir di era kebyar dan terbiasa membaca musik iringan tari dengan pola hitungan satu kali delapan, perlu perjuangan untuk memahami pola-pola gending rejang desa kuna. Kapan awal, kapan akhirnya, para penari itu seolah tanpa komando, tiba-tiba mulai menari, dan tiba-tiba berhenti. Cara mereka menjadi 'seragam' sungguh menakjubkan. Tim rekonstruksi yang di dalamnya termasuk tetua adat, berupaya menginterpretasi struktur Rejang Pala mengikuti beberapa ketentuan yang wajib hadir pada prosesi rejang, serta menyesuaikan dengan struktur upacara Usaba Desa. Struktur tarinya dibagi dalam mataki-taki (bersiap), masolah (menari), makideh/pakideh (melingkar/ mengitari) yang dilihat dari unsur dinamika merupakan bagian klimaks, dan panyawis (penyelesaian). Namun prosesinya diawali dengan mendak Ida Batara Dalem. Pada prosesi ini, rejang dibagi dua kelompok besar. Satu kelompok menunggu di Pura Balang Tamak, mendak Ida Batara Dalem Kupa; dan satu kelompok besar menunggu di Bale Pegat, mendak Ida Batara Dalem Nongan. Kedua kelompok ini kemudian bertemu di Pura Pasamuhan Agung. Sebelas rejang daha mengikuti prosesi ngaturang pamendak di jeroan pura, sementara rejang lainnya menunggu di balai banjar Bucu. Pada momen inilah, penata melihat beberapa hal menyangkut etika penari yang masih harus ditata atau dikondisikan oleh desa. Misalnya

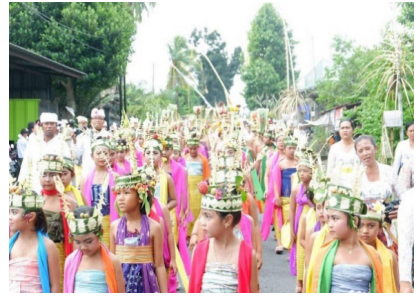

Gambar 9: rejang alit pada saat makebah (foto: Widarma Yatra, 2019)

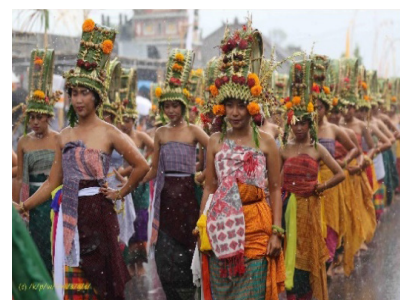

Gambar 10 : rejang daha pada saat makebah (foto: Parwatha Wijaya, 2019)

serobong yang diletakkan di sembarang tempat. Pada metoda konstruksi paling akhir, Smith mengingatkan untuk mereview kembali seluruh elemen untuk melihat kesatuan atau keutuhan karya. Untuk mencapai kesatuan itu seorang penata memerlukan pengalaman yang baik serta kesadaran artistik yang tinggi, tetapi dapat dikenali baik oleh orang awam. Kesatuan dan keutuhan karya pada rejang, tidak dapat dilihat secara koreografi saja melainkan keutuhannya sebagai ritual. Ritual yang sanggup memberi daya hidup kepada setiap kehidupan, setidaknya pada lingkungan terdekatnya dalam hal ini adalah desa setempat. Untuk itu upaya penguatan ekosistem atau revitalisasi setelah rekonstruksinya patut diupayakan.

\section{Musik}

Sekaa gong yang ngayah saat rekonstruksi 1984 adalah sekaa Gong Banjar Bujaga. Gending (musik) yang ditabuh pada saat Rejang Pala di pundut tidak bersifat khusus diperuntukkan untuk Rejang Pala, melainkan mengikuti prosesi murwa daksina atau mider. Gending yang digunakan disebut gending nglegong, menggunakan perangkat gamelan gong kebyar, dan masih diwariskan hingga sekarang. Data ini dengan segera dapat dibantah otensitasnya. Gong Kebyar diperkirakan lahir pada tahun 1914, sedangkan Rejang Pala menghilang di tahun 1917 akibat gejor. Jika merunut jejak Rejang Pala, kaitannya dengan Pura Balang Tamak sebagai pura ulun suwi/ hulu subak, tradisi Usaba Pala, penyebutan puseh oleh sebagian krama desa Nongan untuk pura Balang Tamak, dan tinggalan artefak terkait dengan mitos Pan Balang Tamak, kiranya Rejang Pala sejaman dengan rejang yang lahir dari tradisi puja pari di desa-desa kuna. Pada Kakawin Mayantaka, Karya Danghyang Nirartha (Agastia, 2018), salah satu teks yang dipercaya sebagai rujukan dalam menelusuri asal muasal rejang, menyebut berbagai jenis alat musik, salah satunya gambang. Wirama ke-43 yang menyebut tentang rejang, pada bait ke 10 


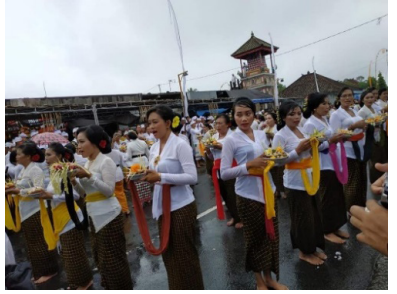

Gambar 11 : rejang lingsir pada saat makebah (foto: Sinaryati, 2019)

berbunyi: Ri teleb ikang suka makon angalapa gamelan wawang dateng/ Muni gambang ing Pujung awarna leyep gerehing labeh Kapat// (terjemahan: dari asiknya beliau menikmati keindahan, lalu menyuruh mengambil gambelan, dan segera datang/ suara gambelan Gambang dari Pujung bagaikan keindahan suara petir di bulan Kapat (Oktober)//. Pada bait ke 13 kemudian berbunyi Sira mulaning rejang I Bali Nagara tuhu katwang ing manis/ beliau adalah mengawali adanya rejang di Bali, yang sungguh-sungguh dihormati karena kemanisannya/. Uraian tentang rejang berlanjut sampai bait ke 17 . Teks ini dapat dijadikan sebagai salah satu referensi mengenai gamelan rejang. Beberapa rejang kuningan di kecamatan Abang, Kabupaten Karangasem masih ada yang mewariskan gambang sebagai gamelan rejang, ada juga gong gede, bahkan ada yang sudah menggunakan gong kebyar. Di beberapa wilayah Karangasem yang mewarisi tradisi selonding, seperti Tenganan Pagringsingan, Bungaya, Asak, Timbrah, Selat Duda, dan lainnya menggunakan selonding dalam rangkaian ritual rejang-nya. Selonding diperkirakan populer di Bali dan Jawa pada abad XI-XIV, tersebar hampir di seluruh kabupaten di Bali (Tusan, 2001: 137-147). Terkait selonding, desa Nongan memiliki mitos bahwa pada tegalan dekat Pura Balang Tamak, terdapat areal yang tidak dapat ditumbuhi pohon apapun, konon di bawahnya tertanam slonding warisan Pan Balang Tamak. Keabsahan mitos ini tentu belum dapat dibuktikan sebelum dilakukan penggalian. Cok Sawitri menyebutkan bahwa desa Nongan sebagai desa tua termuat dalam prasasti Landih B = Nongan B. Angka tahunnya 1103 S disaat kekuasaan Jayapangus. Dalam prasasti tersebut bukan rejang yang ditulis tetapi mengenai tiga alat musik bila dimiliki desa itu akan dikenai pajak yakni salunding, galunggang dan calung (wawancara 27 Juli 2020).

Tim sepakat mengganti instrumen gong kebyar. Interpretasi mangku dalang Made Yoga Pranata selaku penata musik adalah menggunakan selonding, sesuai data-data yang telah disampaikan di atas. Namun, berbagai kendala teknis dalam proses, membuat penata musik memutuskan untuk menggunakan gamelan gambang miliknya. Proses penciptaan musik dan tari berjalan masing-masing, tetapi konsep telah dibahas dan disepakati sejak awal. Penata musik mengirimkan komposisi tabuh bagian mataki-taki hingga masolah dalam bentuk rekaman via WhatsApp pada tanggal 18 Maret 2019. Sejak pertama kali mendengar komposisi musik ini, penata merasa karakteristik tabuh yang dibuat sangat pas dengan karakteristik geraknya. Gerak yang telah penata rangkai, penata pasangkan dengan mudah pada komposisi musiknya. Penyesuaian yang dilakukan hanya menyangkut ritme gerak tanpa mengubah motif gerak. Hal lain adalah penyesuaian teknis, yaitu berapa kali pengulangan gending harus dilakukan, mengingat barisan rejang ini begitu panjang.

Tahapan akhir rekonstruksi imajinatif Rejang Pala adalah historiografi, yaitu menyampaikan hasil-hasil rekonstruksi imajinatif masa lampau sesuai dengan jejak-jejaknya. Pada tahap ini pelaku rekontruksi dihadapkan pada persoalan kemahiran mengarang atau art of writing (Herlina, 2014: 16). Pada kasus rekonstruksi tari, sebagaimana sifat tari yang 'sesaat' (hilang seusai pertunjukan dan hanya meninggalkan kesan), diperlukan upaya revitalisasi terus menerus. Oleh karena itu penelusuran jejaknya tidak cukup dengan menelusuri sejarah tarinya saja, patut diikuti dengan pemetaan ekosistem (daya hidup) yang membentuknya di masa lampau dan menguatkannya di masa yang akan datang. Historiografi mengenai keberadaan Rejang Pala telah dituliskan pada artikel berjudul "Rejang di Pura Balang Tamak, Warisan Budaya Desa Nongan”, pada jurnal Segara Widya 2018. Historiografi pada konteks tarinya adalah pementasan tarian tersebut. Pada tahap ini pelaku rekonstruksi dihadapkan pada persoalan kemahiran 'mengarang' tari, meminjam istilah Doris Humphrey disebut sebagai the art of making dance. Pementasan perdana (makebah) telah dilakukan pada Usaba Desa tanggal 9 April 2020. Pada saat usaba di Pura Balang Tamak, 8 Februari 2020, sepuluh bulan setelah makebah, hasil rekonstruksi Rejang Pala digelar kembali dengan ketentuan jumlah sebelas rejang daha. Persiapan hingga pementasan rejang dikoordinir oleh pasraman desa (lembaga pendidikan non formal desa adat Nongan) dan prajuru (pengurus) Pura Balang Tamak, tanpa intervensi ataupun kehadiran penata. Sebelas serobong yang lama tetap dibuat oleh tukang banten, sementara cucu-cucu mereka menarikan Rejang Pala hasil rekonstruksi. Demikianlah secara alami masyarakat beradaptasi pada perubahan tanpa harus mencederai keyakinan mereka. Tahun ini, desa sedianya menggelar kembali usaba desa (termasuk ritual rejang) pada 10 Mei 2020, tetapi pelaksanaannya ditangguhkan karena pandemi covid-19.

\section{WUJUD KARYA}

Wujud karya merupakan capaian akhir setiap penciptaan karya seni. Wujud dalam karya seni merupakan sesuatu yang dapat dinikmati oleh penikmat dan mempunyai dua unsur utama, yakni bentuk (form) dan susunan (structure) (Djelantik, 1990: 14). Bentuk dan struktur Rejang Pala telah dikaji dan disampaikan dalam artikel "Tari Rejang Pala Desa Nongan, Kecamatan Rendang, Kabupaten Karangasem: Kajian Bentuk dan Fungsi”, pada jurnal Mudra volume 35, oleh I Wayan Adi Gunarta \& Satyani (2020). Pada rekonstruksi imajinatif, wujud karya yang 
ditampilkan pada makebah 9 April 2019, bukanlah pencapaian akhir. Ia masih memerlukan upaya revitalisasi berupa penguatan ekosistem, sehingga Rejang Pala dapat melakukan fungsi ritualnya secara utuh.

\section{SIMPULAN}

Rekonstruksi imajinatif Rejang Pala merupakan kegiatan mengkonstruksi kembali bentuk dan struktur tari Rejang Pala yang sudah punah, menggunakan pemikiran imajinatif berdasarkan metoda sejarah dan metoda konstruksi tari. Tahapan heuristik dan kritik dimulai sejak tahun 2017. Interpretasi mengenai koreografinya dilakukan dalam kurun waktu empat bulan, sejak Januari hingga makebah pada 9 April 2019. Historiografi Rejang Pala tersaji dalam dua bentuk yaitu penulisan kembali sejarahnya dan pementasan kembali wujud tariannya, diikuti dengan penulisan proses rekonstruksi imajinatifnya serta kajian bentuk dan fungsinya sebagai bentuk pertanggungjawaban akademik. Rekonstruksi imajinatif Rejang Pala tidak berakhir pada wujud karya yang telah disajikan pada saat makebah. Wujud karya ini akan terus beradaptasi dengan upaya revitalisasi atau penguatan ekosistem yang dilaksanakan sejak tahun 2020. Penguatan ekosistem ini bertujuan agar Rejang Pala dapat memenuhi fungsi ritualnya dalam arti yang luas. Tidak sebatas pada tarian yang melengkapi pelaksanaan upacara, tetapi mampu memberi dan menjaga daya hidup lingkungan sekitarnya sebagaimana makna ritual itu sendiri.

Bercermin pada pelaksanaan rekonstruksi imajinatif hingga makebah, penata menemukan beberapa hal yang patut dijadikan pertimbangan dalam penguatan ekosistem Rejang Pala, yaitu: ketersediaan penari, karena jumlah penari rekonstruksi ini masih berdasarkan antusiasme warga; ketersediaan buah dan kelengkapan serobong yang belum optimal, dan hal ini terkait dengan penguatan potensi subak; pengorganisasian pelaksanaannya meliputi teknis persiapan, prosesi yang dilalui rejang, serta kelengkapan upakaranya; pengkondisian oleh desa dalam memberi tuntunan etika dan disiplin kepada rejang; pengaturan hak dan kewajiban krama desa yang terlibat dalam ritual rejang; serta ketentuan pemeliharaan sarana prasarana rejang (gamelan, kostum, serobong, dan lain sebagainya). Butir-butir refleksi ini hendaknya dijadikan pertimbangan pada penyusunan panyacah awig rejang desa Nongan.

\section{DAFTAR RUJUKAN}

Agastia, I. B. G. (2018). Kakawin Mayantaka: Karya Danghyang Nirartha. Taman Sastra Wagiswari Dharmasabha.

Bandem, I Made, \& F. E. deBoer. (2004). Kaja dan Kelod, Tarian Bali dalam Transisi. Badan Penerbit Institut Seni Indonesia Jogjakarta.
Djelantik, A. A. M. (1990). Pengantar Dasar Estetika Jilid I: Estetika Instrumental. STSI Denpasar.

Gunarta, I. W. A., \& Satyani, I. A. W. A. (2020). Tari Rejang Pala Di Desa Nongan, Kecamatan Rendang, Kabupaten Karangasem: Kajian Bentuk Dan Fungsi. Mudra Jurnal Seni Budaya, 35(2), 172-181. https://doi.org/10.31091/ mudra.v35i2.1049

Herawati, K. P., \& Prihatini, N. S. (2019). Rekonstruksi Tari Bedhaya Endhol-Endhol Oleh Gusti Kanjeng Ratu Wandansari Di Kraton Kasunanan Surakarta Hadiningrat. Gelar: Jurnal Seni Budaya, 16(2), 168. https://doi. org/10.33153/glr.v16i2.2489

Herlina, N. (2014). Metoda Sejarah (revisi cet). Yayasan Sejarawan Masyarakat Indonesia (YMSI).

Mariasa, I. N. (2015). Rejang Kuningan di Kecamatan Abang Kabupaten Karangasem, Bali: Aspek Bentuk, Fungsi, Dan Makna. Pasca Sarjana Universitas Gajah Mada Yogyakarta.

Rianta, I. M., Santosa, H., \& Sariada, I. K. (2019). Estetika Gerak Tari Rejang Sakral Lanang Di Desa Mayong, Seririt, Buleleng, Bali. Mudra Jurnal Seni Budaya, 34(3), 285-393. https://doi.org/10.31091/mudra.v34i3.678

Ruspawati, I. A. W. (2016). Legong Tombol di Desa Banyuatis, Buleleng, Bali Rekonstruksi dan Regenerasi. In Mudra Jurnal Seni Budaya (Vol. 31, Issue 1). https:// doi.org/10.31091/mudra.v31i1.245

Satyani, I. A. W., \& Gunarta, I. W. A. (2018). Rejang Di Pura Balang Tamak, Warisan Budaya Desa Nongan. 6(1), $1-9$.

Suharto, B. (1985). Jacqueline Smith: Komposisi Tari, Sebuah Petunjuk Praktis Bagi Guru (1985 edisi). IKALASTI Yogyakarta.

Susanti, N. N. K. A., Seramasara, I. G. N., \& Arshiniwati, N. M. (2019). Kajian Rekonstruksi Tari Legong Raja Cina Di Puri Taman Saba, Blahbatuh, Gianyar Sebuah Proses Kreatif. Kalangwan, Jurnal Seni Pertunjukan, 5(1), 7-20.

Tedjoworo, H. (2001). Imaji dan Imajinasi. Penerbit Kanisius.

Tusan, P. W. (2001). Selonding. Dinas Kebudayaan Propinsi Bali.

\section{WEBTOGRAFI}

Armaya, I P. (2014, Agustus 24) Tari Rejang Desa Pedawa (Video). You Tube, https://m.youtube.com/ watch?v=AAG7mHSemEA 
Vinartha, R. Y. (2016, Oktober 4) Tarian Rejang Kayu Putih (Video). You Tube, https://m.youtube.com/ watch?v=jb02VR8mUos

\section{DAFTAR INFORMAN}

Asti, Ni Putu. (53 th), Pangayah (pembuat upakara di Pura Balang Tamak), wawancara 11 Februari 2017 di Pura Balang Tamak, Desa Nongan, Rendang, Karangasem.

Darmayani, Ida Ayu Putu (45 th), Generasi pertama Rejang Pala rekonstruksi 1984, wawancara 26 Juni 2016 di Geria Bujaga, Br. Ambengan, Desa Nongan, Rendang, Karangasem.

Dibia, I Wayan (72 th), Guru Besar ISI Denpasar, wawancara 26 Juli 2020 via telepon, Br. Mukti, Singapadu, Kecamatan Sukawati, Gianyar.

Dwipayana, Ida Made. (44 th). Bendesa Adat Nongan Perioda 2009-2014, wawancara 10 Agustus 2020 di rumahnya, Jl Pasekan Gang Batu Permata, No 12, Batubulan, Sukawati Gianyar.

Ida Pedanda Istri Ratna Kanya. (65 th). Pendeta dan Ahli Upakara (Tapini), wawancara 20 Agustus 2020 (via telepon), 12 Februari dan 26 Juni 2017, di Geria Alangajeng, Br. Nongan Kaler, Desa Nongan, Rendang, Karangasem.

Ida Pedanda Gde Nyoman Djelantik Dangin. (75 th). Pendeta dan Bendesa Adat Nongan Perioda 1976-1993, wawancara 12 Februari dan 26 Juni 2017, di Geria Alangajeng, Br. Nongan Kaler, Desa Nongan, Rendang, Karangasem.

Sawitri, Cok. (51 th). Budayawan \& Penulis, wawancara 29 Juli 2020 di rumahnya, Jl. Batanghari XIC No. 6b, Panjer, Denpasar. 